\title{
Scots Pine (Pinus sylvestris) dynamics in the Welsh Marches during the Mid to Late Holocene
}

DOI:

10.1177/0959683621994654

\section{Document Version}

Final published version

Link to publication record in Manchester Research Explorer

\section{Citation for published version (APA):}

Sassoon, D., Fletcher, W., Hotchkiss, A., Owen, F., \& Feng, L. (2021). Scots Pine (Pinus sylvestris) dynamics in the Welsh Marches during the Mid to Late Holocene. The Holocene, 31(6), 1033-1046.

https://doi.org/10.1177/0959683621994654

\section{Published in:}

The Holocene

\section{Citing this paper}

Please note that where the full-text provided on Manchester Research Explorer is the Author Accepted Manuscript or Proof version this may differ from the final Published version. If citing, it is advised that you check and use the publisher's definitive version.

\section{General rights}

Copyright and moral rights for the publications made accessible in the Research Explorer are retained by the authors and/or other copyright owners and it is a condition of accessing publications that users recognise and abide by the legal requirements associated with these rights.

\section{Takedown policy}

If you believe that this document breaches copyright please refer to the University of Manchester's Takedown Procedures [http://man.ac.uk/04Y6Bo] or contact uml.scholarlycommunications@manchester.ac.uk providing relevant details, so we can investigate your claim.

\section{OPEN ACCESS}




\title{
Scots pine (Pinus sylvestris) dynamics in the Welsh Marches during the mid to late-Holocene
}

\author{
Dael Sassoon, ' (iD William J Fletcher,' Alastair Hotchkiss, ${ }^{2}$ \\ Fern Owen' and Liting Feng'
}

\begin{abstract}
Around 4000 cal yr BP, Scots pine (Pinus sylvestris) suffered a widespread demise across the British Isles. This paper presents new information about $P$. sylvestris populations found in the Welsh Marches (western central Britain), for which the long-term history and origins are poorly known. Two new pollen records were produced from the Lin Can Moss ombrotrophic bog (LMI8) and the Breidden Hill pond (BHI8). The LMI8 peat core is supported by loss-on-ignition, humification analysis and radiocarbon dating. Lead concentrations were used to provide an estimated timeframe for the recent BHI8 record. In contrast to many other Holocene pollen records from the British Isles, analysis of LMI8 reveals that Scots pine grains were deposited continuously between c. 6900-300 cal yr BP, at frequencies of $0.3-5.4 \%$. It is possible that individual Scots pine trees persisted through the wider demise on thin soils of steep droughtprone crags of hills or the fringes of lowland bogs in the Welsh Marches. At BHI8, the record indicates a transition from broadleaved to mixed woodland, including conifer species introduced around AD 1850 including Picea and Pinus. The insights from BHI8 suggest that the current populations may largely be the result of planting. Comparison of the LMI 8 findings with other regional pollen records highlights consistent patterns, including a Mid-Holocene maximum (ca. $7000 \mathrm{cal}$ yr BP), long-term persistence at low pollen percentages and a Late-Holocene minimum (ca. $3000 \mathrm{cal}$ yr BP). These distinctive trends encourage further studies on refugial areas for Scots pine in this region and elsewhere.
\end{abstract}

\section{Keywords}

palaeoecology, pine-decline, Pinus sylvestris, Scots pine, Shropshire, Welsh Marches

Received 16 October, 2020; revised manuscript accepted I5 January, 202 I

\section{Introduction}

Since its arrival in the early Holocene after the onset of full interglacial conditions, between approximately $11,000-10,000 \mathrm{cal}$ yr BP, Pinus sylvestris spread rapidly across the British Isles and reached its maximum extent $\sim 4500$ cal yr BP (Bennett, 1984; Birks, 1989; Birks et al., 1975; Kinloch et al., 1986). Palaeoecological data, however, shows that $P$. sylvestris suffered a widespread demise around $4000 \mathrm{cal}$ yr BP (Gear and Huntley, 1991). While this demise was sudden in places, an increasing body of research has demonstrated that the timing and nature of this event are far from uniform (Blackford et al., 1992; Edwards et al., 1996; Edvardsson et al., 2016; Hall et al., 1994, 1996; Lageard et al., 1999, Payne et al., 2013). The decline has been attributed to various factors including climatic deterioration, increased competition with other tree species, anthropogenic effects, pathogens and volcanic activity (Bennett, 1984, 1995; Blackford et al., 1992; Hall et al., 1996; Manning et al., 2010; McGeever and Mitchell, 2016).

Efforts to conserve and restore woodland habitats and species has stimulated discussions about the protection of native tree species (McGeever and Mitchell, 2016) and the control of introduced non-natives (Shackelford et al., 2013). In the British Isles, one such debate revolves around the range of native $P$. sylvestris outside of the Scottish Highlands (Manning et al., 2010).

Currently, the accepted view is that populations of native Scots pine (descendants of populations from the early Holocene) are geographically isolated to the Scottish Highlands and only survive in fragmented woodlands (Figure 1). In the rest of the British Isles, Scots pine is believed to only exist in plantation forests established in the 1800 s, and as individual 'landscape trees' planted from the middle of the 17th century onwards (Kinloch et al., 1986). However, several authors (e.g. McGeever and Mitchell, 2016; McNally and Doyle, 1984; Manning et al., 2010) have suggested the persistence of native populations in southern Scotland, northern England and western Ireland long after the demise, thus indicating the existence of possible refugial zones.

Living P. sylvestris specimens are found in ancient semi-natural woodlands (ASNWs) in the Marches of north-east Wales and Shropshire, occurring on thin-soils of drought-prone crags located in a small area centred around Breidden Hill and nearby Nesscliffe Hill. Observations at the site revealed that the thin soils overlaying the doleritic crags of Breidden Hill support unique calcifuge-calcicole heath and 'saum' habitats (Mortimer et al., 2000; Natural England, 2007). Rare post-glacial relic flora is

\footnotetext{
'Department of Geography, The University of Manchester, UK ${ }^{2}$ Woodland Trust, Kempton Way, Grantham, Lincolnshire, UK

\section{Corresponding author:}

Dael Sassoon, Quaternary Environments and Geoarchaeology, Department of Geography, School of Environment, Education and Development, The University of Manchester, Arthur Lewis Building, Manchester, MI3 9PL, UK.

Email: dael.sassoon@manchester.ac.uk
} 


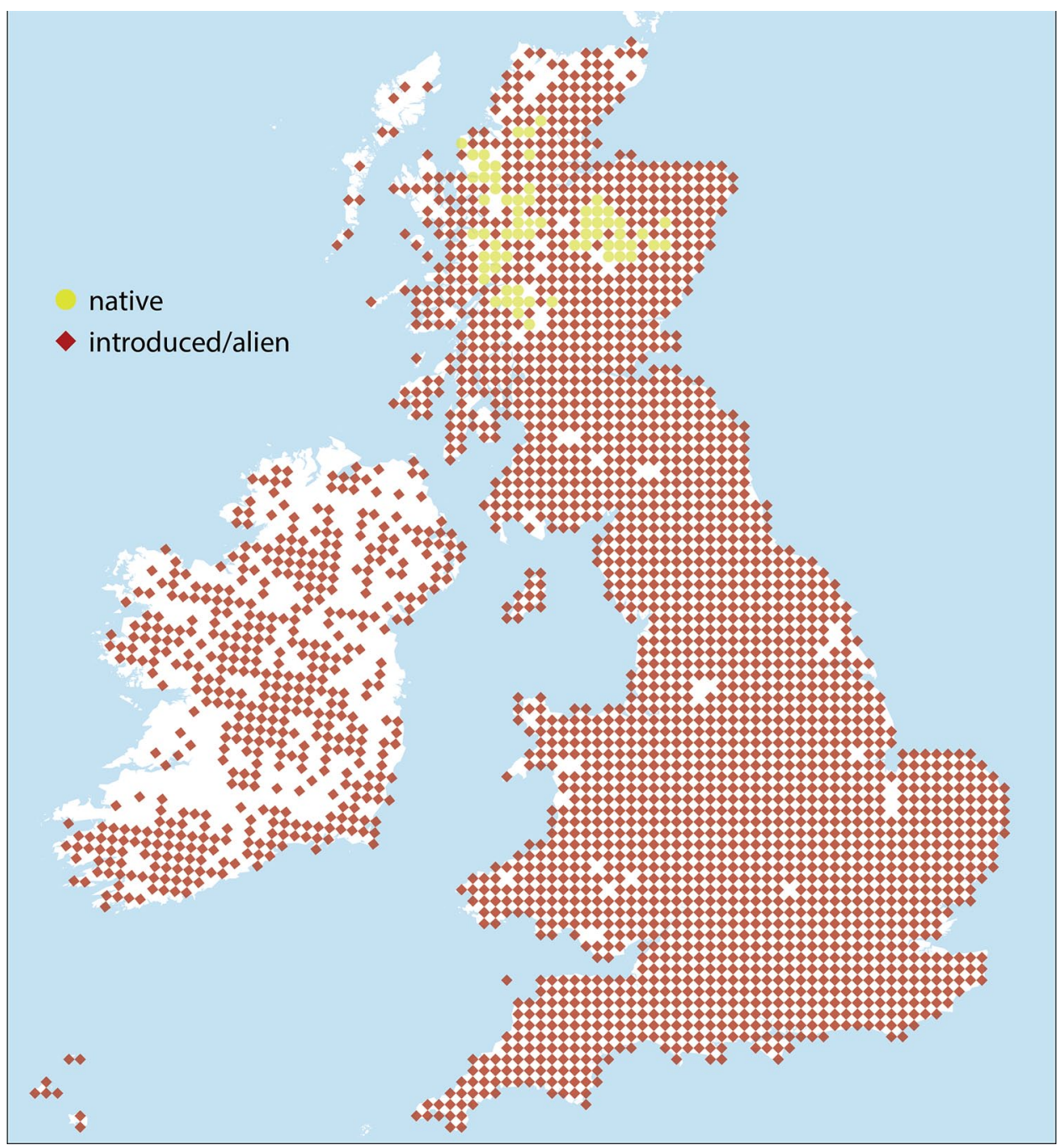

Figure I. Current distribution of native Scots Pine in the British Isles (adapted from Botanica Society of Britain and Ireland (BSBI), 20I8).

present, including Potentilla rupestris, Silene viscaria, Veronica spicata, and a range of whitebeam microspecies including the endemic Sorbus stirtoniana. Considered a non-native species, conservation efforts have involved the removal of Scots pine trees from the crags at Breidden Hill to reduce the impacts of shading and the build-up of needle litter on the important flora. Tree-rings from felled trees at Breidden Hill suggest that some of these individuals were over 100-150years old and, given their location, would most likely have regenerated naturally from seed. Scots pine can produce seed from a relatively young age (10-15 years; Mukassabi et al., 2012) so the planting date need not necessarily have been much earlier than the age of these naturalised individuals. The symbology of the 1838 Tithe map of Breidden Hill clearly shows a mixed woodland with conifer and broadleaved tree symbols across the whole hill, including the inaccessible crags and more gentle gradients. However, there are no existing historical records that indicate the origin of these Scots pine populations, raising a question about whether they are remnants of native populations that survived the demise, they have been planted more recently, or they are naturalised stands that self-seeded from planted stock.

Some findings from previous studies suggest the long-term presence of Scots pine in the area. Buckland et al. (2001) studied the record of beetle assemblages from the Buckbean pond site to investigate human activity on Breidden hill during the Iron Age. Notably, the investigation reported a specimen of a Hylurgops palliatus beetle, dated at between ca. 2100 and $2200 \mathrm{yrs}$ BP. Hylurgops palliatus is an ambrosia beetle which is an obligate associate of Scots Pine. Moreover, between 2011 and 2013, entomologists
(Jones, 2011; Rotheray, 2013) recorded a rare species of hoverfly, Callicera rufa, among these hills. This species is also an obligate of water-filled rot-holes in Scots pine and previously thought to occur only in ancient Caledonian pinewoods in Scotland (Jones, 2011), although this has since been found at other sites, such as in South Wales and Merseyside. Another archaeological study on Breidden hill was conducted by Musson et al. (1991), who used pollen analysis on lake sediments from the Buckbean pond to understand changes in local environmental conditions over time. The pollen record shows that Pinus grains occur long after the pine-decline, with abundances of $5-10 \%$ between 3000 and $2000 \mathrm{cal}$ yrs BP, and occasional zero values. However, there is no further discussion about this species' history, as the focus is mostly on the archaeology of the site.

Other tantalising evidence that might point towards the longterm persistence of Scots pine in this area includes fragments from Ancient Welsh literature. Early references to pine in Welsh (ffenitwydd, ffenyt, ffinydwydd) occur in manuscripts such as Cad Godeu (The Battle of the Trees) and the Mabinogion, dated to the 13th century (Ball et al., 1990). Pine is also mentioned in The Dream of Rhonabwy, a medieval Welsh text found exclusively in the Red Book of Hergest, written c. AD 1382 (Raye, 2014). In the tale of the Lady of the Fountain in the Mabinogion, the character of Cynon talks about "branches greener than the greenest pinetrees" (Guest, 1877). The reference to pine in these examples is interesting because at the time these myths were told, Scots pine is generally considered to have been extinct in the region. This contradiction might be either because Scots pine was present in Wales during the medieval period, or the Welsh words for pine 

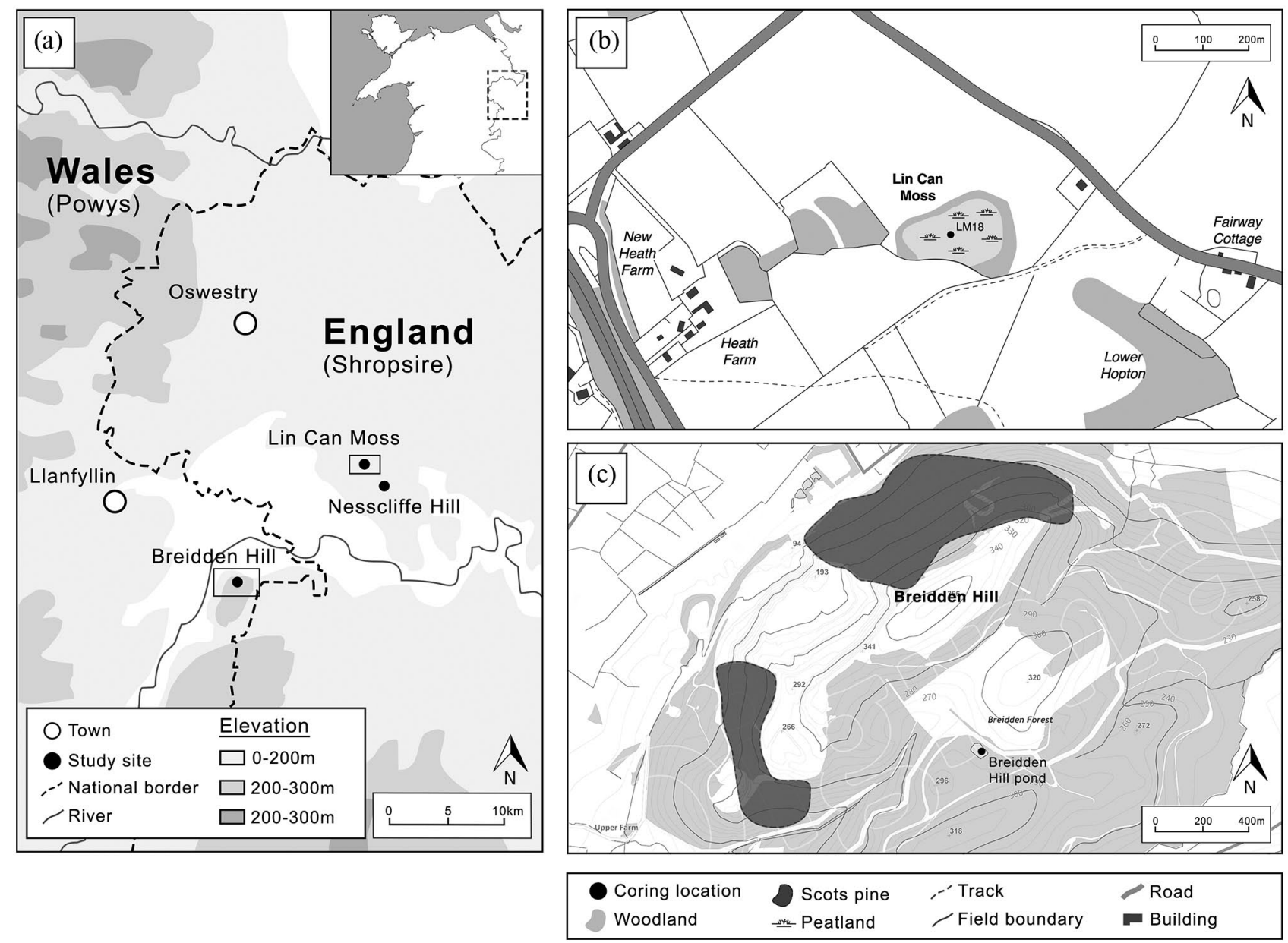

Figure 2. (a) Regional map showing the location of the study sites. (b) Map of the Breidden Hill coring location. (c) Map of the Lin Can Moss (LMI8) coring location.

could have referred to native yew or juniper trees which existed at that time (Raye, 2014).

This paper aims to shed further light on the origin of Scots pine specimens in the Breidden and Nesscliffe hills area. Specifically, we seek to understand whether there might be woodland remnants which have descended from older native generations (Carlisle and Brown, 1968), or if they are all of more recent planted origin. The study will focus on the history of Scots pine in the Welsh Marches by studying the palaeoecology of peat and lake deposits, providing a deep-time perspective of the dynamics of Scots pine in this area taking into account factors such as longterm succession, anthropogenic impact and climatic change.

\section{Study setting}

Two previously unstudied sites were selected in the vicinity of Breidden and Nesscliffe Hills, located in northwest Wales on the Shropshire-Powys border and approximately $15 \mathrm{~km}$ west of Shrewsbury (Figure 2a). Breidden Hill (367 m asl) is an outcrop of basic igneous rock associated with shales, sandstones, and mudstones (Watts, 1885), and is a site of archaeological significance for Iron age and Late Bronze Age forts (Buckland et al., 2001). Nesscliffe Hill (161 m asl), the geology of which was famously described by Charles Darwin in 1831 (Herbert and Roberts, 2002), is a red sandstone escarpment that is known for an Iron Age hillfort where Late Roman artefacts have been found (Home and Jones, 1959; Murdie et al., 2003). Both hills are characterised by several introduced conifer plantations including Picea sp., Tsuga heterophylla and Pseudotsuga menziesii, estimated to have been planted in the 1800s (Linnard, 1982). The climate in Shropshire is temperate, with an average temperature of $8.8^{\circ} \mathrm{C}$ and rainfall averaging $700 \mathrm{~mm} / \mathrm{yr}$ (Climate-Data.org, 2019).

The site of Lin Can Moss (SJ 375 211) was chosen as the main coring site. This is a small (1.61 ha) raised ombrotrophic peat bog located near Nesscliffe Hill in north Shropshire, about $10 \mathrm{~km}$ from Breidden Hill and $15 \mathrm{~km}$ from Shrewsbury (Figure 2b). It is classified as a Site of Special Scientific Interest (SSSI) under the protection of the Wildlife and Countryside Act 1981 (Natural England, 2018). The site is dominated by non-arboreal species such as Sphagnum recurvum, Carex rostrata, Carex curta, Eriphorum vaginatum and Vaccinium oxycoccus, with a surrounding woodland fringe including Betula, Fraxinus, Alnus, Quercus and P. sylvestris (Natural England, 2018) (Figure 2b).

At Breidden Hill (Figure 2c), a small ( $0.3 \mathrm{ha}$ ) pond of about $2 \mathrm{~m}$ deep, located on the southern side of Breidden Hill was selected for further study. We note that the previously studied Buckbean Pond site (Buckland et al., 2001) no longer exists due to quarrying activity. The pond is considered to have been constructed in the 1800 s as a fire-fighting reservoir and is currently surrounded by both PAWS (Plantation on Ancient Woodland Sites) and ASNW. The vegetation adjacent to the pond consists of Pteridium aquilinium, Holcus mollis, Filipendula ulmaria as well as Betula sp., Fraxinus excelsior, Quercus sp., Sorbus aucuparia and Picea sitchensis.

\section{Materials and methods}

\section{Core retrieval}

A sediment core (LM18; Figure 2b) was sampled from Lin Can Moss $\left(52^{\circ} 47^{\prime} 02.1^{\prime \prime} \mathrm{N} 2^{\circ} 55^{\prime} 39.9^{\prime \prime} \mathrm{W}\right)$ using a Russian corer and overlapping segments, reaching the bottom of the deposit at 
$310 \mathrm{~cm}$. The top $85 \mathrm{~cm}$ of the core were not successfully sampled due to the high Sphagnum moss content, therefore only the remaining $225 \mathrm{~cm}$ were used for the pollen analysis. The core was transported to the University of Manchester Geography Laboratories, where it was cleaned and described using the Troels-Smith system (Troels-Smith, 1955), and stored at $4^{\circ} \mathrm{C}$.

At the Breidden Hill pond, a UWITEC gravity corer was used to collect sediment core (BH18) to ensure the soft sediments from the base of the pond were collected without being disturbed (Ribeiro et al., 2008). The corer was dropped from an inflatable rubber boat in the middle of the pond $\left(52^{\circ} 43^{\prime} 05.9^{\prime \prime} \mathrm{N} 3^{\circ} 02^{\prime} 36.1^{\prime \prime} \mathrm{W}\right)$ (Figure 2c). A $46.5 \mathrm{~cm}$ sediment core was recovered and transported vertically to the laboratory to avoid sediment mixing. In the laboratory, the sediment core was extruded in $1 \mathrm{~cm}$ sections which were each placed into individual sample bags.

\section{Peat characterisation}

Loss-on-ignition (LOI) was carried out to determine the percentage of organic matter in the LM18 peat core. Samples of around $3 \mathrm{~cm}^{3}$ were taken at a $2 \mathrm{~cm}$ interval. After oven-drying wet samples for $24 \mathrm{~h}$ at $105^{\circ} \mathrm{C}$, the dry organic matter was combusted at $550^{\circ} \mathrm{C}$ (Heiri et al., 2003). Peat humification was carried out at a $2 \mathrm{~cm}$ interval on the LM18 core. Following the methods indicated by Chambers et al. (2011), freeze-dried samples of approximately $0.1 \mathrm{~g}$ were ground to a fine powder, and subsequently boiled at $95^{\circ} \mathrm{C}$ in an $8 \% \mathrm{NaOH}$ solution for $1 \mathrm{~h}$ to dissolve humic matter. The samples were then filtered through a Whatman Qualitative one glass fibre filter, and the filtrate was measured three times with a spectrophotometer at $540 \mathrm{~nm}$ to obtain a light transmission percentage (Chambers et al., 2011).

\section{Chronology}

Wood macro-fossils were collected from the LM1 8 core and dated using radiocarbon dating, at the depths $90 \mathrm{~cm}$ and $300 \mathrm{~cm}$. Peat samples were passed through a coarse sieve and single fragments of waterlogged wood were manually picked under a zoom microscope using clean tweezers. The material was sent to Beta Analytic for dating. A palynological control point for the chronology was added, based on the well-known elm-decline occurring regionally between 3400 and $4400 \mathrm{cal}$ yr BP (Chambers, 1980; Musson et al., 1991; Taylor, 1973). The radiocarbon dates (95.4\% probability) were calibrated using IntCal20 (Reimer et al., 2020) and the $2 \sigma$ calibrated median ages (cal yr BP) were rounded to the nearest 10 years. Age-depth modelling (linear interpolation between the three ages) was undertaken using the CLAM R package (Blaauw, 2010).

The chronology for the Breidden Hill core was established by measuring lead $(\mathrm{Pb})$ concentrations and lead isotopic ratios $\left({ }^{206} \mathrm{~PB} /{ }^{207} \mathrm{~Pb}\right)$ and comparing results to existing lead records, yielding an approximate timeframe for the accumulation of the lake sediments (Renberg et al., 2001; Kemp et al., 2012). The use of lead concentrations and isotopic ratios to construct chronologies for sediment records has been demonstrated by Renberg et al. (1994, 2001). Renberg et al. (1994) identified three main peaks in a record from Sweden corresponding to Roman, Medieval and historical 20th century anthropogenic activity, respectively, with parallels across Europe (Renberg et al., 2001). In central Britain, historical lead emissions increased already from the 16th century onwards due to regional smelting activity, and especially in the mid-19th century due to fossil fuel combustion (Fletcher and Ryan, 2018; Le Roux et al., 2004; Rothwell et al., 2010). The ${ }^{206} \mathrm{~Pb} /{ }^{207} \mathrm{~Pb}$ ratio can be used to trace the source of lead in sediments and consequently distinguish between natural and anthropogenic sources. Average ${ }^{206} \mathrm{~Pb} /{ }^{207} \mathrm{~Pb}$ ratio in the Earth's crust is $\sim 1.2$ but varies with the underlying geology (Chow et al., 1975). Due to the lower ratio of lead ores (e.g. 1.17 for Roman and
Medieval lead in Britain, 1.18-1.19 for British coals, 1.04-1.17 for petrol additives), lower values, especially in combination with absolute increases in $\mathrm{Pb}$ concentration, can be a powerful tool for detecting anthropogenic pollution in the historical timeframe (Farmer et al., 1999; Renberg et al., 2001). Lead isotopic ratios $\left({ }^{206} \mathrm{~Pb} /{ }^{207} \mathrm{~Pb}\right)$ were determined using inductively coupled plasma mass spectrometry (ICP-MS). The samples were freeze-dried, ground and sub-sampled $(0.2 \mathrm{~g})$. Each sub-sample was then prepared using standard Aqua Regia microwave digestion in a CEM Mars Xpress system, using 9:1 $\mathrm{HNO}_{3}: \mathrm{H}_{2} \mathrm{O}_{2}$ as the digestion reagent before dilution and transfer to centrifuge tubes for analysis. The samples were measured three times on a PerkinElmer Nexion 350D and then averaged by the instrument.

\section{Pollen records}

In the laboratory, $1 \mathrm{~cm}^{3}$ samples were taken from the LM18 and BH18 cores at $8 \mathrm{~cm}$ and $2 \mathrm{~cm}$ intervals, respectively. Pollen extraction followed standard laboratory techniques outlined by Moore et al. (1991) and Faegri and Iversen (1989). During the process, Lycopodium spores were added to each sample in order to determine the absolute pollen concentration (Bennett and Willis, 2001). Pollen was identified by comparison with reference material and pollen atlases (e.g. Moore et al., 1991) under $\times 400$ and $\times 1000$ magnifications. For each sample, a main sum of 300 pollen grains of terrestrial plants (trees, shrubs, herbs, grasses and sedges) were identified (Bennett and Willis, 2001) excluding spores, and aquatic species. Microcharcoal fragments were also identified as they can be an indicator of fire events and anthropogenic activity (Blackford, 2000; Brown, 2010). The pollen diagrams were created using the software Psimpoll (Bennett, 1996), and have been divided into distinct zones using Optimal Splitting by Information Content.

\section{Results}

\section{Lin Can Moss}

The two radiocarbon dates reveal a basal age of $6060 \pm 30 \mathrm{cal}$ yr BP (6910 cal yr BP) and an age of $270 \pm 30 \mathrm{cal} \mathrm{yr} \mathrm{BP} \mathrm{(320} \mathrm{cal} \mathrm{yr}$ BP) for the uppermost part of the recoverable peat deposit (Table 1). The age-depth model is presented as a component of the pollen diagram (Figure 3 ). The chronology suggests that the sedimentation rate at the site is slow, although with the absence of more dates it is not possible to identify changes in sedimentation or hiatuses. The chronology also indicates that peat accumulation at Lin Can Moss accelerates between $85 \mathrm{~cm}$ and the surface of the bog. This is reflected by the composition of the uppermost part of the core $(0-85 \mathrm{~cm})$, composed of largely unhumified and highly elastic Sphagnum moss.

There is a rapid transition of LOI from low (52\%) to high (96\%) values near the base of the core $(310-290 \mathrm{~cm})$, followed by predominantly high LOI values above $95 \%$ between 287 and $97 \mathrm{~cm}$. In the uppermost part of the core $(95-89 \mathrm{~cm})$, organic matter drops slightly from $95 \%$ to $81 \%$.

The humification results (Figure 3) show a general increase in humification throughout the core, reflected by a decrease in percentage transmission. The lowest humification levels occur at the bottom of the core, indicated by a peak in transmission values of 49-57\%. Subsequent noteworthy high transmission values (low humification) occur at $245 \mathrm{~cm}(47 \%)$ and $199 \mathrm{~cm}$ (42\%). Transmission values then fluctuate around $20-35 \%$ between 200 and $150 \mathrm{~cm}$, until reaching the lowest values (high humification) of around $12-19 \%$ between 140 and $130 \mathrm{~cm}$. Transmission increases to $38 \%$ in the uppermost sample at $89 \mathrm{~cm}$ depth, indicating a final decrease in humification.

The major changes in the LM18 pollen diagram (Figure 3) are summarised in Table 2. The pollen record indicates a transition 
Table I. Radiocarbon dates from the LMI8 record.

\begin{tabular}{lcclcccc}
\hline Lab ID & Core & $\begin{array}{l}\text { Depth } \\
(\mathrm{cm})\end{array}$ & Material & $\delta 13 C(\%)$ & $\begin{array}{l}\text { Conventional } \\
\text { radiocarbon } \\
\text { age (BP) }\end{array}$ & $\begin{array}{l}2 \text { sigma calibrated } \\
\text { age range } \\
(\text { cal yr BP) }\end{array}$ & $\begin{array}{l}\text { Median age } \\
(\text { cal yr BP) }\end{array}$ \\
\hline BETA-526878 & LMI8 & 90 & Wood macrofossils & -26.5 & $270 \pm 30$ & $0-440$ & 318 \\
BETA-500379 & LMI8 & 290 & Wood macrofossil & -27.5 & $6060 \pm 30$ & $6796-7146$ & 6913 \\
\hline
\end{tabular}

from dense forest characterised by high concentrations of Quercus, Betula, Corylus and Alnus, to more open land as \%NAP increases towards zones LM-4 and LM-5. Pinus pollen is deposited continuously throughout the record at low concentrations between 0.3 and $5.4 \%$.

\section{Breidden Hill}

BH18 comprises organic detrital mud overlying clays. The $\mathrm{Pb}$ concentration (Figure 4) shows low values of $16 \mathrm{mg} / \mathrm{kg}$ at the base of the core, a first rise to around $55 \mathrm{mg} / \mathrm{kg}$ above $35 \mathrm{~cm}$ followed by a second rise to peak values (around $69-88 \mathrm{mg} / \mathrm{kg}$ ) in the central core section $(27-12 \mathrm{~cm})$, and a subsequent decrease to around $65 \mathrm{mg} / \mathrm{kg}$ above $12 \mathrm{~cm}$. The ${ }^{206} \mathrm{~Pb} /{ }^{207} \mathrm{~Pb}$ ratio (Figure 4) is generally high (1.18-1.19) in the lower part of the core below $27 \mathrm{~cm}$ depth, decreasing slightly with decreasing depth. The ratio then shows a progressive shift to lower values between $28 \mathrm{~cm}$ and $22 \mathrm{~cm}$ (values decreasing from 1.178 to 1.139 ). The values then fluctuate between 1.135 and 1.143 in the upper part of the core.

The major vegetation dynamics observed from the pollen analysis of BH18 (Figure 4) are summarised in Table 3. The record suggests that the site underwent a transition from an environment characterised by high levels of Alnus and ferns (BH-1) to a forest with broadleaf species such as Quercus and Betula (BH2). A significant rise in conifer cover is observed, with increases in P. sylvestris and Picea (BH-3 and $\mathrm{BH}-4)$.

\section{Discussion}

\section{Vegetation dynamics during the mid to late-Holocene at Lin Can Moss}

At the site of LM18, radiocarbon dating indicates that peat initiation began no later than around $7000 \mathrm{cal} \mathrm{yr} \mathrm{BP.} \mathrm{Between} 7000 \mathrm{cal}$ yr BP and $3000 \mathrm{cal}$ yr BP (zones LM-1 and LM-2), the pollen record indicates a landscape dominated by Quercus, Betula, Corylus, Ulmus and Alnus, reflecting the earlier expansion of broadleaved woodland that is understood to have occurred during the Early Holocene based on the nearby record of Colemere (Kneen and Lageard, 2015). The high abundance of pine in the lowermost sample of the LM18 record suggests that pine may have been relatively abundant prior to $7000 \mathrm{cal}$ yr BP, an inference again supported by the Colemere record (Kneen and Lageard, 2015). In fact, $P$. sylvestris was among the pioneer species to arrive in Shropshire after the post-glacial period along with Betula and Corylus (Beales, 1980; Kneen and Lageard, 2015; Twigger and Haslam, 1991). Pinus then becomes less abundant for the rest of the record apparently outcompeted by other species, specifically Quercus, Ulmus and Alnus. In particular, the expansion of Alnus during the Early and Mid-Holocene caused significant competition with P. sylvestris and Betula (Kneen and Lageard, 2015). The expansion of Alnus has been attributed to a shift to wetter and more oceanic climatic conditions, (Beales, 1980; Mighall and Chambers, 1995), which is supported in the LM18 core by the lower degree of humification in zones LM-1 and LM-2. Sphagnum also increases at this time, suggesting a local transition from carr to bog.

The decrease in Ulmus in LM-2 correlates to the well-known Holocene biogeographical event of the 'elm-decline' (Parker et al., 2002). As previously noted, the elm-decline in this region appears to have occurred later than elsewhere in the British Isles (Godwin, 1940), around 4000-3500 cal yr BP as opposed to the more widely recognised time window of $5000-5500 \mathrm{cal}$ yr BP (Innes et al., 2006; Parker et al., 2002). This late regional elmdecline is supported by similar findings by Musson et al. (1991), who record the elm decline at Breidden Hill at about 2400 BC (4400 cal yr BP), and other similarly later dates in Wales, at Glas Llyn (3870 $\pm 100 \mathrm{cal}$ yr BP; Taylor, 1973) and Cefn Gwernffrwd (3845 \pm 80 cal yr BP; Chambers, 1980).

The LM1 8 record shows a decline of pine around $3400 \mathrm{cal} \mathrm{yr}$ $\mathrm{BP}$ with values dropping from around $5 \%$ to $<1 \%$ and reaching an absolute minimum around $3000 \mathrm{cal}$ yr BP (LM-3). Several authors (e.g. Anderson et al., 1998; Bennett, 1995; Bradshaw and Browne, 1987; Gear and Huntley, 1991; Lageard et al., 1999; McGeever and Mitchell, 2016) suggest that the pine-decline was caused by a shift from a drier climate to wetter and cooler conditions, promoted by large-scale changes in global atmospheric circulation coupled with a reduction in solar insolation (Anderson et al., 1998). At LM18, the pine decline occurs in the context of drying conditions in the bog, inferred by the decreasing transmission values in the humification record, as well as the low Sphagnum abundances coupled with an increase in Calluna vulgaris (Figure 3). It is possible that the humification record misses a regional climate trend that was unfavourable for Scots pine, and the values reflect a localised drying trend resulting from infilling of the site. The pine decline in this area might have also been caused by increased human pressure on the woodland landscape, as proposed by Bennett (1995) or by competition with other species such as Alnus, pathogens or even soil deterioration (Bennett, 1984). We rule out the possibility of impacts from volcanic activity such as the Hekla-4 eruption 4500 cal yr BP (Blackford et al., 1992), as the pine decline at LM18 occurred around one thousand years later.

Nevertheless, Pinus at Lin Can Moss maintains values above $0.3 \%$ and recovers by the end of zone LM- 4 , reaching $1.5 \%$. Pinus then rises further to $3.5 \%$ at $85.5 \mathrm{~cm}$ in zone LM-5. The data indicate that although recorded in low abundances throughout the core, $P$. sylvestris pollen grains were deposited continuously even after the pine-decline. The local humification record seems to indicate a prolonged dry shift between 3400 and 2000 cal yr BP, which could mean that Scots pine in this area may have benefitted from a drier environment shortly after the pinedecline. It is also possible that the isolation and inaccessibility of trees on the steep crags of Breidden and Nesscliffe Hills, as well as the thin soils, could have promoted the persistence of Scots pine in this area. These hills may have acted as a refugial zone, providing $P$. sylvestris enough protection against climate deterioration, competitive exclusion by more dominant trees, expansion of blanket bogs and anthropogenic activity. Similar findings have been reported by McGeever and Mitchell (2016) at Rockforest in Ireland, where $P$. sylvestris persisted on limestone pavements which discouraged the conversion of woodland into agricultural land.

The first significant evidence of human disturbance to the vegetation in the area can be seen at the beginning of zone LM-3, dated around $3400 \mathrm{cal}$ yr BP. Quercus pollen declines, accompanied by a gradual decrease of Alnus and an increase in Plantago 

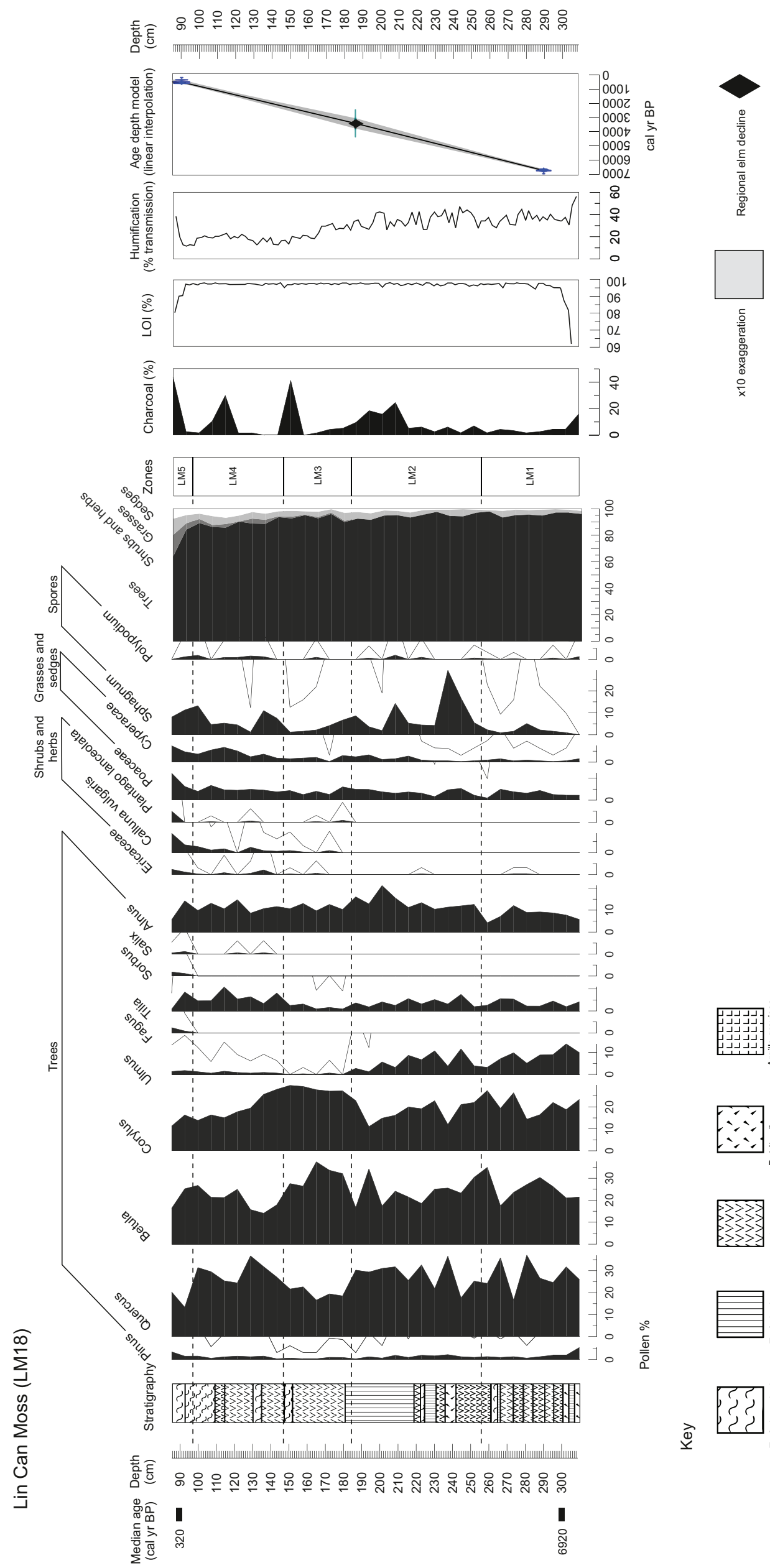
Table 2. Zone summary for the LMI8 record.

\begin{tabular}{|c|c|c|c|}
\hline Zone & Depth $(\mathrm{cm})$ & $\begin{array}{l}\text { Estimated age } \\
\text { (cal yr BP) }\end{array}$ & Description \\
\hline LM-5 & $96-85$ & $750-320$ & $\begin{array}{l}\text { Betula, Corylus and Quercus are the dominant species although less prevalent as non-arboreal taxa increase. Fagus } \\
\text { and Sorbus appear at the site. Ericaceae, Calluna vulgaris, Poaceae, Cyperaceae and Sphagnum increase signifi- } \\
\text { cantly. Pinus abundances rise towards the end of the zone. }\end{array}$ \\
\hline LM-4 & $147-96$ & $2100-750$ & $\begin{array}{l}\text { Quercus and Tilia reach peak concentrations while Betula and Corylus decrease. Pinus shows a stable but low } \\
\text { abundance. Ulmus also reappears, although below previous average. \%NAP and microcharcoal levels increase. }\end{array}$ \\
\hline LM-3 & $183-\mid 47$ & $3400-2100$ & $\begin{array}{l}\text { Pinus declines to less than }<1 \% \text { but does not disappear. Betula, Corylus and Alnus frequencies increase in the near } \\
\text { absence of Ulmus, Pinus and Tilia. Quercus suffers a significant decline towards the middle of the zone. Arrival of } \\
\text { Ericaceae, Plantago lanceolata and Calluna vulgaris, and increase in Poaceae and Cyperaceae. }\end{array}$ \\
\hline LM-2 & $255-183$ & $5600-3400$ & $\begin{array}{l}\text { Quercus, Betula, Corylus, Ulmus and Alnus are the prevalent species. Rise in Sphagnum and micro-charcoal, and } \\
\text { decrease in Betula, Corylus, Ulmus and Tilia. Ulmus and Pinus decline steadily. }\end{array}$ \\
\hline LM-I & $310-255$ & $7000-5600$ & $\begin{array}{l}\text { Dominated by Quercus, Betula, Corylus, Ulmus and Alnus. Highest concentration of Pinus at the lowermost part } \\
\text { of the zone. Rise in Alnus, Quercus and Betula, and decline in Corylus, Ulmus and Tilia. Poaceae, Cyperaceae and } \\
\text { Sphagnum increase towards the end of the zone. }\end{array}$ \\
\hline
\end{tabular}

lanceolata and Poaceae, indicating a period of opening of the forest by Neolithic populations (Musson et al., 1991). This corroborates findings at Fenmere, Shropshire, showing an expansion of cereals and herbs where Tilia, Ulmus and Quercus were cleared for agriculture and timber, especially during the early Bronze Age (Twigger, 1988; Twigger and Haslam, 1991).

Clearance episodes seem to intensify in zone LM-4, around 2100 cal yr BP, during the Roman occupation (Beales, 1980). Musson et al. (1991) describe in detail the high degree of occupation of the Breidden Hill during the late Iron Age and Romano-British period, and indicates intense pressure on the environment with increased levels of Artemisia, Chenopodiaceae, Polygonum bistorta type, Plantago major/media and Fabaceae. In zone LM-5, further human impact is shown by decreases in Betula and Corylus and increases in Ericaceae and Calluna vulgaris, as well peaks in the micro-charcoal record, which may indicate a decrease in woodland cover by means of slash-and-burn agriculture during the Norman conquest in the 11th century AD (Beales, 1980; Linnard, 2000; Mighall and Chambers, 1995). The decrease in tree pollen, namely of Betula, Quercus, Corylus, Tilia and Alnus, at the end of zone LM- 5 can be attributed to the increase in pastoral and agricultural activities between the 14th and 17th centuries $\mathrm{AD}$, as well as significant political and societal change in Wales during this time which promoted the exploitation of woodlands for building and timber (Beales, 1980; Linnard, 2000; Rackham, 1986).

The layer of unhumified sphagnum in the uppermost $85 \mathrm{~cm}$ of the core, which was not recoverable with a Russian corer, could relate to a more recent rise in waterlogging in the bog of Lin Can Moss. This is supported by the uppermost values in the percentage transmission record, which indicate very weak humification. This transition to wetter conditions is estimated to have occurred at around $320 \mathrm{cal}$ yr BP $(440-0 \mathrm{cal}$ yr BP, $2 \sigma)$. This waterlogging may have been initiated during the Little Ice Age (LIA) as shown by peat-based palaeohydrological studies in the UK, such as Tore Hill Moss in Scotland, and Malham Tarn Moss and May Moss in northern England, which recorded wet changes during LIA between AD 1350 and 1640 (Blundell and Barber, 2005; Chiverrell, 2001; Turner et al., 2014). This could have caused wetter conditions in the acrotelm (Belyea and Warner, 1996), a decrease in decomposition of Sphagnum moss and an increased accumulation of unhumified material. Wetter conditions at the site could have also caused a reduction in herbaceous and woody cover, leading to an increased Sphagnum cover.

\section{Recent insights from the Breidden Hill record (AD 1800-present)}

Based on comparison with other records from the British Isles (Farmer et al., 1999; Fletcher and Ryan, 2018), the BH18 lead concentration and ${ }^{206} \mathrm{~Pb} /{ }^{207} \mathrm{~Pb}$ ratios reflect trends that would be expected during the 19th and 20th centuries. Farmer et al. (1996) and Fletcher and Ryan (2018) found a rapid increase in lead concentrations in NW England and Scotland respectively, associated with an increase in pollution due to industrialisation during the 19th century. This was supported by Mighall et al. (2002a, 2002b) who found a similar trend at two sites in the Ystwyth Valley as a result of an increase in mining activity during this period. It is likely that the rapid increase in lead concentrations from Breidden Hill, which begins at around $35 \mathrm{~cm}$, can be correlated to this national rise in lead contamination, and perhaps more specifically to mining activities in mid-Wales during the 1850 s (Mighall et al., 2002a, 2002b). This was occurring on the opposite side of Breidden Hill at Criggion Quarry (Hanson Heidelberg Group, 2013), and in the nearby Snailbeach and Tankerville Mines of Shropshire (Pearce, 2010), and the North Wales Coalfield (Jones, 2008). The precise origin of this pond, however, is not fully understood. One hypothesis is that it was created artificially as a fire-fighting reservoir around in the 1800s. Another explanation is related to the creation of the Criggion Quarry in 1866 (Hanson Heidelberg Group, 2013). In the mid-19th century, clay-lined reservoirs were created to provide a year-round water supply for steam-powered machines used for mining (Bick, 1996; Edwards et al., 2016). After the 1930s, deposition of lead associated with coal burning and smelting, as well as the introduction of leaded petrol, begins to lower ${ }^{206} \mathrm{~Pb} /{ }^{207} \mathrm{~Pb}$ ratios (Shennan et al., 2015). Farmer et al. (1996) recorded a decrease in ${ }^{206} \mathrm{~Pb} / 207 \mathrm{~Pb}$ ratios from background levels of $1.17-1.18$ to 1.122 by the 1970 s. Based on these results, it is not possible to provide a detailed chronology for the record, but an approximate date of around AD 1850 (100 cal yr BP) for the initiation of lake sediment accumulation can be provided for depth of $35 \mathrm{~cm}$, and likely post-1930s age for the core section above $26 \mathrm{~cm}$ depth.

The palaeoecological significance of zone BH-1, therefore, must also be treated with caution, as this zone corresponds to the predominantly clay-rich sediments which may have been transported to the site as part of the construction of the pond. Nevertheless, high frequencies of Alnus and Corylus in BH-1 suggest a wooded and damp environment (Clapham et al., 1962; Ingrouille, 1995), supported by very high abundances of Thelypteris, a species characteristic of alder carr (McVean, 1956). The high presence of Sparganium grains may reflect the development of a telmatic zone around the pond margins as the site underwent hydroseral succession (Van der Valk, 1981). The lack of Quercus in this zone is surprising due to its near continuous representation in pollen records from nearby sites including Crose Mere (Beales, 1980), Colemere and Clarepool Moss (Kneen and Lageard, 2015) and LM18. This could be owed to the significant prior felling of Quercus during the early late 18 th and early 19th centuries, as a result of the need for timber in the naval industry and oak bark in 


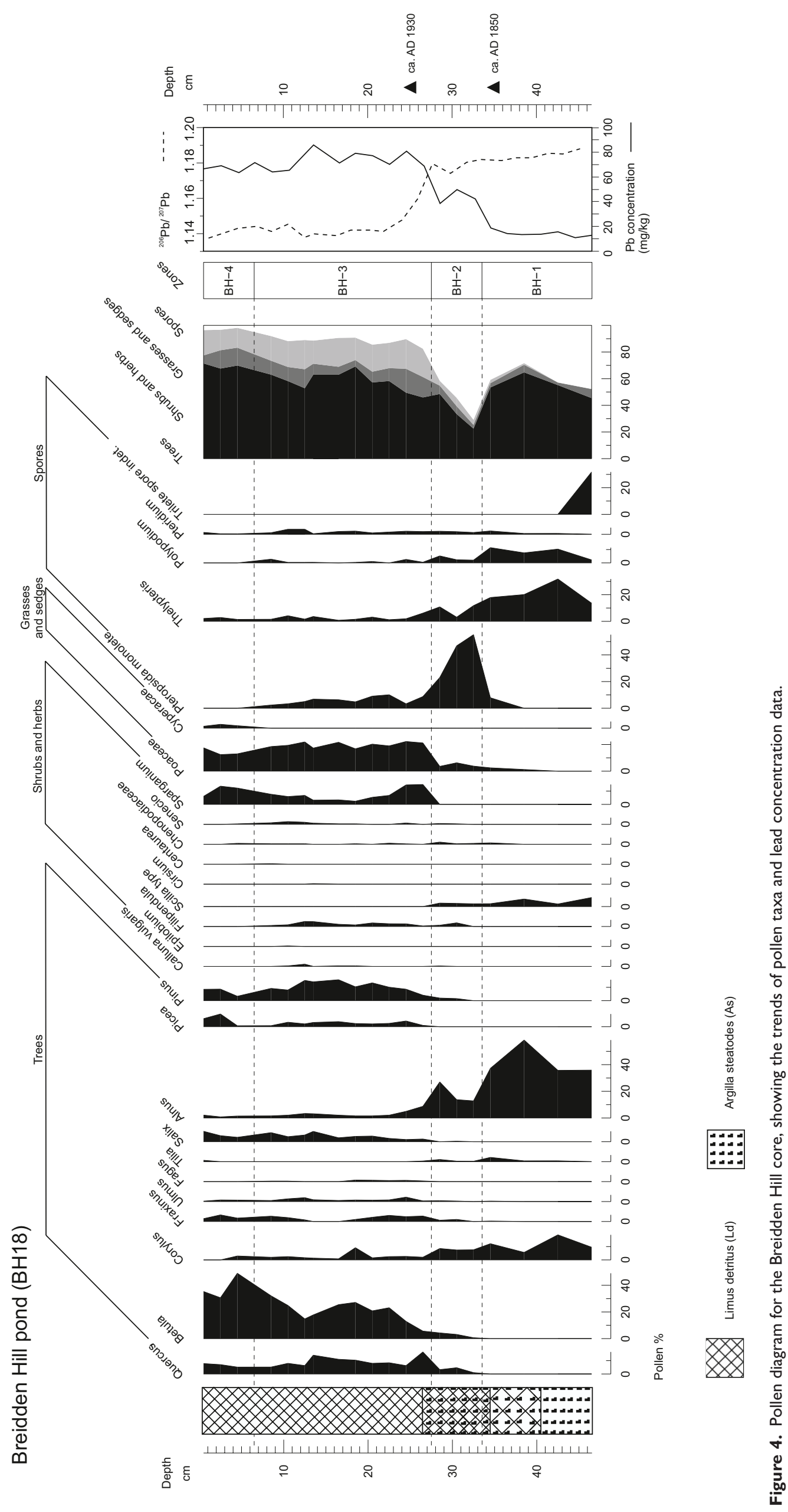


Table 3. Zone summary for the Breidden Hill BHI 8 record.

\begin{tabular}{|c|c|c|}
\hline Zone & Depth $(\mathrm{cm})$ & Description \\
\hline $\mathrm{BH}-4$ & $6.5-0$ & $\begin{array}{l}\text { Picea and Pinus increase towards the end of the record, coinciding with a decline of Betula. Salix and Fraxinus persist at steady } \\
\text { frequencies, while Corylus disappears. Sparganium and Poaceae are present at moderate values throughout the zone. Pterop- } \\
\text { sida monolete disappears. }\end{array}$ \\
\hline $\mathrm{BH}-3$ & $27.5-6.5$ & $\begin{array}{l}\text { This zone is dominated by Betula, Quercus and Pinus. Fraxinus and Salix are present at lower frequencies. Picea appears in this } \\
\text { zone but remains at abundance below throughout the zone. Sparganium, Pteropsida monolete and Thelypteris are all present at } \\
\text { low frequencies. Betula and Quercus decline around the middle of the zone. Poaceae is present at high values. Pinus and Picea } \\
\text { decrease. }\end{array}$ \\
\hline $\mathrm{BH}-2$ & $33.5-27.5$ & $\begin{array}{l}\text { Alnus and Corylus dominate this zone. Quercus and Betula appear but remain at low frequencies. This zone records the first } \\
\text { appearance of Pinus. Pteropsida monolete is the prominent NAP. The end of this zone is characterised by decreases in Alnus, } \\
\text { Corylus and Pteropsida monolete. There is also the first appearance and rapid increase of Sparganium and an increase in } \\
\text { Poaceae. }\end{array}$ \\
\hline $\mathrm{BH}-\mathrm{I}$ & $46.5-33.5$ & $\begin{array}{l}\text { Characterised by high frequencies of Alnus and Corylus. NAP such as Thelypteris and Polypodium are present at high values. } \\
\text { Poaceae is present at very low but slowly increasing frequencies. The end of this zone is characterised by a decrease in Alnus } \\
\text { and the appearance and rapid increase of Pteropsida monolete. }\end{array}$ \\
\hline
\end{tabular}

the tanning industry (Linnard, 2000; Rackham, 1990). However, the very high percentage of ferns in this zone could be an indication of poor pollen preservation leading to the loss of other taxa, especially considering the high clay content of these sediments (Horrocks and D'Costa, 2003). At the end of zone BH-1, the marked decrease in Alnus pollen may indicate a shift towards drier conditions (Lamb, 1977), due to the sensitivity of Alnus to hydrological changes (Rodríguez-González et al., 2014). Another explanation for the decline in Alnus at this time is clearance in advance of the extensive plantation of conifers, which began during the 19th century (Rackham, 1990). This is supported by the immediate appearance of Picea and Pinus in Zone BH-2 once the frequency of Alnus has decreased significantly.

The absence of Pinus in the pollen record up until this point and the widespread planting at this time events suggest it was most likely introduced via planting during this period at this location. However, the absence of Pinus before this point may also be due to the potentially allochthonous nature of the clay layer in the sediment in zone BH-1, which may not accurately reflect the full picture of the woodland forest composition. This might also be why Quercus does not show the same trends as in records from adjacent sites (e.g. Beales, 1980; Kneen and Lageard, 2015; Musson et al., 1991). Equally, the high pollen productivity of alder at the site in this zone seems to have dominated the pollen spectra, possibly 'swamping' the record and pushing the signal of scattered individual pine trees below the palynological radar.

In Zone BH-3, the high values of Betula $(>25 \%)$ reflect an increase in birch trees, perhaps a secondary succession following clearing activities implied by the reduction in Alnus. This zone is particularly noteworthy as it represents significant changes in the woodland species composition, with a rise in Pinus, Picea and Fagus pollen. The increase in abundance of these species is attributed to the widespread planting of nonnatives in Wales which began around AD 1850 (Linnard, 2000). Douglas fir (Pseudotsuga menziesii), for instance, was first introduced in Britain in AD 1827 and the first plantings in Wales were established at Penrhyn Castle in AD 1840, at Powis Castle in AD 1842 and at Stanage in AD 1854 (Linnard, 2000). The strong palynological signal in BH-3 might however reflect more extensive plantation activity from the 1930s onward, consistent with the low ${ }^{206} \mathrm{~Pb} /{ }^{207} \mathrm{~Pb}$ ratios observed in this core section. We note some similarities between the uppermost zone of LM18 and the zones BH-3 and BH-4. However, on the basis of the available chronological information, it is unlikely that the records overlap chronologically.

In Zone BH-4, the woodland is still dominated by Betula and other broadleaved species, but their presence decreases rapidly near the top of the core as Pinus and Picea increase. This could have occurred as a result of the widespread plantations of conifers by the Forestry Commission following World War II (Rackham, 2008).

\section{Did Scots pine survive the decline in this area?}

Given there are not hiatuses in sedimentation, the palynological evidence shows that $P$. sylvestris pollen was continuously deposited at the site of Lin Can Moss between $7000 \mathrm{cal} \mathrm{yr} \mathrm{BP}$ and $300 \mathrm{cal}$ yr BP, with abundances between $0.3 \%$ and $5.4 \%$. Could P. sylvestris have persisted in the local area since the Mid-Holocene? The continuous curve for Pinus at Lin Can Moss provides tantalising, though not unassailable, support for a continuous local presence of pines at low abundances. The pollen values clearly do not suffice as evidence of a local woodland where Scots pine was dominant or abundant similar to, for example, a present-day Caledonian pinewood. Nevertheless, the findings may support the presence of isolated trees in a mixed forest scenario, occurring in microedaphic conditions that enabled their growth. The recent insights from the Breidden Hill record show that the concentration of Scots pine pollen, even when the trees are physically present at the site, remain under $10 \%$. Thus, the levels in the fossil diagram may reflect a population of $P$. sylvestris similar to the modern one, with a few individual trees confined to the steep crags of the hills.

There has been considerable debate as to the abundance of pollen that indicates the local presence of pine, mainly because of the high pollen productivity of the species and the efficiency with which the pollen can travel long distances (Lageard et al., 1999; McGeever and Mitchell, 2016; Pessi and Pulkkinen, 1994). Over the last 30-40 years, the view about what palynological threshold indicates the local presence of pine has changed considerably. An increasing number of studies, particularly from Ireland, have suggested the presence of pine even with low pollen abundances. Fossitt (1994) demonstrated the local presence of pine woodlands in NW Ireland by using pine stomata, even when pollen frequencies in the record were as low as $3-18 \%$. Similarly, Hall et al. (1994) found pine macrofossils occurring contemporaneously with low abundances of pine pollen $(2-3 \%)$ in a record from Garry Bog, Ireland. A later study by Cooney (1996) showed that P. sylvestris occurred locally in Ireland at $2.3 \%$. Froyd (2005) further reported that $P$. sylvestris may be local with abundances of only $0.4 \%$, using once again evidence from fossil pine stomata. In Scotland, where native pinewoods have been continuously present, Tipping (2008) recorded pine pollen percentages between 10 and $20 \%$ after the pine-decline.

Although the palynological evidence points towards a continuous deposition of local Scots pine pollen, there is still a chance that the record may reflect a well-mixed atmospheric pollen component including pine pollen from distant sources, such as Scotland and Ireland (see section below). The modest size of the 
LM18 basin $(50 \times 120 \mathrm{~m})$, however, makes it unlikely that the long-distance pollen component is dominant, and the pine pollen signature is therefore more likely to represent local land cover changes (McGeever and Mitchell, 2016; Sugita, 2007).

\section{Regional comparisons}

The continuity of the pine curve, though admittedly at low values, is unlike many other fossil records in the rest of the British Isles and especially in Wales (Figure 5). For instance, the pollen diagram of Goldcliff in SW Wales (Smith and Morgan,1989) presents breaks in the Pinus record around $4750 \mathrm{cal} \mathrm{yr} \mathrm{BP}$ and $3750 \mathrm{cal} \mathrm{yr}$ BP. Similarly, at Cors Fochno in western Wales, Mighall et al. (2017) report disruption episodes at $4500 \mathrm{cal} \mathrm{yr} \mathrm{BP}$ and $2000 \mathrm{cal} \mathrm{yr}$ BP. At Tregaron bog in SW Wales, the Pinus record is continuous until 4990 cal yr BP after which it disappears entirely (Hibbert and Switsur, 1976). These trends are all consistent with records from other regional sites in Wales (Figure 5), including Nant Ffrancon (Hibbert and Switsur, 1976), Waun-Fignen-Felen (Smith and Cloutman, 1988), Melynllyn (Walker, 1978) and Arfon Platform (Watkins et al., 2007), where pine reaches the highest abundance around $7000-8000 \mathrm{cal}$ yr BP, and subsequently diminishes and disappears around $4000-5000 \mathrm{cal}$ yr BP. The findings at LM18 are also distinctive when compared to records in England and Ireland, most of which show a discontinuity. For example, at Aveley Marshes in southern England, Batchelor (2009) recorded a

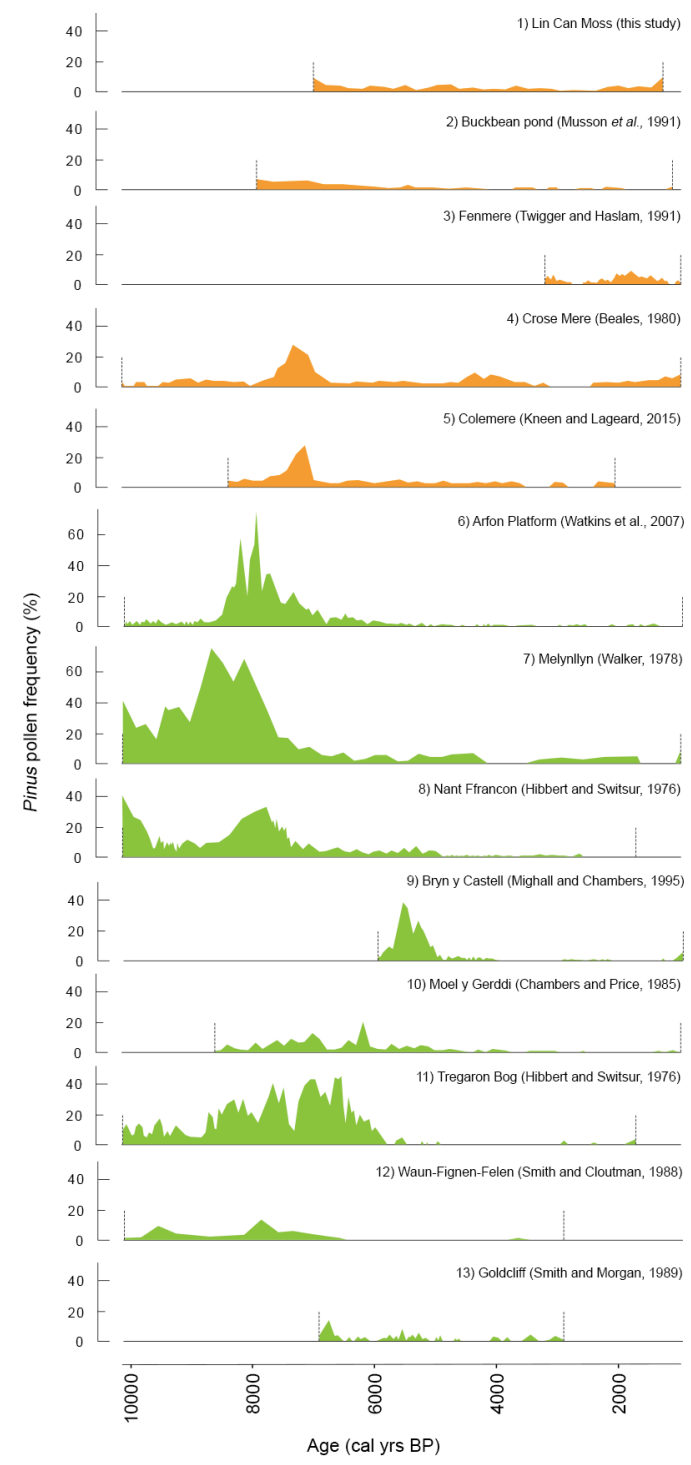

discontinuous pine curve following a decline at $4459 \mathrm{cal}$ yr BP, with recurrent disruptions related to anthropogenic disturbance. Breaks are also recorded in Scotland after the Scots pine range shifted northward following the decline, in pollen records such as Clatteringshaws Loch (Birks et al., 1975) and Loch Cleat (Birks and Williams, 1983). Generally, however, most studies in Scotland report similar findings to LM18 which involve continuous records characterised by higher abundances of about 10-40\% around $6000 \mathrm{cal}$ yr BP and lower abundances of $1-10 \%$ after the decline.

We also find that the Scots pine trends from the LM18 record are consistent with other records in the nearby region, specifically Colemere (Beales, 1980), Crose Mere (Kneen and Lageard, 2015) and Fenmere (Twigger and Haslam, 1991) - all located within $15 \mathrm{~km}$ of Nesscliffe Hill. Figure 5 highlights the good agreement between these records. In all five sites in the Welsh Marches, including Lin Can Moss and Buckbean Pond, pine reaches its highest abundances prior to $7000 \mathrm{cal}$ yr BP with a strong subsequent decline to levels below $10 \%$, revealing a distinctive regional trend of maximum pine cover. It is possible that a shift to wetter conditions and damp soils, coupled with the rise in Alnus promoted by such conditions, led to competition with Pinus in the region (Watkins et al., 2007) and an extirpation of pine except on steep slopes. However, in contrast with lowland Welsh sites at Tregaron Bog and Moel y Gerddi (Chambers and Price, 1988), the Welsh Marches sites show a continued modest persistence of pine throughout much of the Mid to Late-Holocene. The records

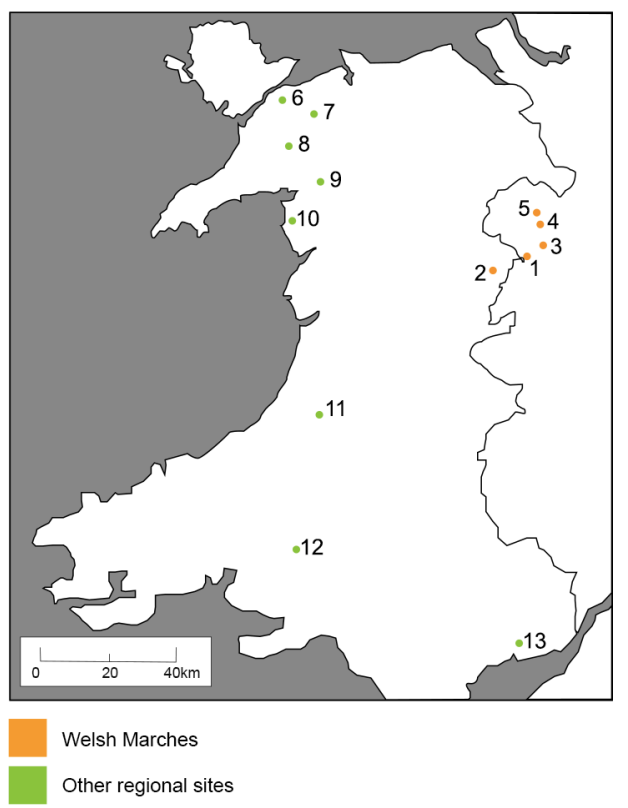

Figure 5. Comparison of the LMI8 record with other dated pine records in Wales that encompass the Mid to Late-Holocene. 
then show a second, well-marked (albeit lower amplitude) decline at $3500-3000 \mathrm{cal}$ yr BP, which corresponds broadly with the demise of pine observed in the rest of the British Isles. After this period of decline, all records show a modest recovery supporting a persistence of Scots pine in the area and abundances rise to between $4 \%$ and $10 \%$. The pine-decline in this area seems to occur later than in many other sites in Wales or England, and the timing can be compared to sites where native Scots pine populations were proven to have survived long after the decline such as the Irish Midlands, where it thrived until 3500 cal yr BP (Dodson and Bradshaw, 1987; McNally and Doyle, 1984).

\section{Are present-day Scots pine stands descendants of older populations?}

Although the results from LM18 support a continued persistence of Pinus pollen throughout the record, the Pinus trends from BH18 indicate that the current population of Scots pine may have been increased or augmented by plantation during the early to mid-1800s. The high degree of naturalisation observed among the modern stands at Breidden Hill and Nesscliffe Hill might be attributed to the existence of environmental conditions that were previously well suited for the successful growth of $P$. sylvestris.

Still, as noted above, the absence of pine pollen in the lowermost part of core BH18 does not necessarily represent evidence of absence of pine trees on or around Breidden Hill, due to the ambiguous origin of basal clays in the pond and possible 'swamping' effect of the alder carr pollen signal. This leaves an open question regarding the persistence of Scots pine during the time elapsed between the end of the LM18 record and the start of the BH18 around. As discussed earlier, uncertainties in the chronology of the records impair the ability to fully interpret environmental changes during this overlap.

Overall, while this study cannot confirm the earlier presence of Scots pine on Breidden Hill prior to the plantations, the evidence from the LM18 core and from the regional Welsh Marches records indicates a strong picture of local recovery of Scots pine following the decline, pointing to a potential role of this region as a refugial area for pine.

\section{Wider relevance and future directions}

Since the 1980s, the Woodland Trust has been protecting the biodiversity of woodlands in Britain, with a great focus on the restoration and expansion of native woodland (Woodland Trust, 2009). Recent efforts have targeted the restoration of ASNWs, which are of significant ecological value (Marren, 1990; Rackham, 2003; Spencer and Kirby, 1992). Although the findings indicate that not all Scots pine in the region descended from older generations, the fossil evidence suggests that the area investigated may have acted as a refugium for a small population to Scots pine, as well as many other post-glacial species. This has important implications for the conservation of Scots pine in the British Isles and for general ecological restoration practices (Manning et al., 2010). According to Gavin et al. (2014), identifying refugial populations and areas of native remnants can be crucial to understanding the importance of certain species in the maintenance of ecosystems over time.

Future research should focus on searching for macrofossils such as bark, wood and cones, or microfossils such as stomata (Twigger and Haslam, 1991) which have not been encountered thus far, to help answer questions about the survival of pine in this part of Shropshire-Wales borders. Further evidence for the persistence of pine could be sought from much wider sources, including continued investigations into the linguistic and documentary references to pine within this part of Wales and the Shropshire borders. DNA analysis could also be carried out on modern and fossil pollen and plant material from existing trees to investigate whether the populations currently found in this part of the British Isles are indeed descendants of older native populations (e.g. Parducci et al., 2005). Environmental DNA analysis might also provide opportunities to look for fossil fungal material of any pine-associated ectomycorrhizal or saprotrophic fungi, such as Suillus and Rhizopogon spp. (Glassman et al., 2015). Lin Can Moss is a valuable site which would be well suited to further investigation using this wider suite of biological proxies, supported by a larger programme of ${ }^{14} \mathrm{C}$ dating. Further palaeoecological sequences would improve our knowledge of the regional history of pines, especially for the critical recent centuries which are not documented in the LM18 core.

\section{Conclusion}

This study aimed to improve understanding of the ecological history of Scots pine populations found in the area of the Welsh marches around Breidden Hill in Powys and Nesscliffe Hill in Shropshire. Radiocarbon dating revealed that the Lin Can Moss peat deposit spans the last $7000 \mathrm{cal}$ yr BP. The LM18 pollen record includes a continuous curve for Pinus between $0.3 \%$ and $5.4 \%$. Pinus declines around 3500 cal yr BP, but never fully disappears and shows a recovery after the demise. This pattern is consistent with other records in the area such as Colemere and Crosemere, where Scots pine seems to have declined much later than other parts of Britain, revealing a distinctive trend for this region on a millennial scale. Elsewhere in Wales and England, pollen records for pine show clear breaks with $0 \%$ abundance, indicating that the trends seen at LM18 are distinctive. Thus, we suggest the long-term persistence of individuals of $P$. sylvestris with a cover similar to present, characterised by the presence of isolated trees on steep slopes in a mixed forest scenario. Insights from the BH18 record show that even with pine trees present at the site today, the abundance of pollen remains below $10 \%$. Of course, on the basis of pollen evidence alone, it is not possible entirely to rule out long-distance travel of pine pollen. However, the consistency of available evidence corroborates the hypothesis of a local Scots pine refugium in the Welsh Marches.

Another aim of this investigation was to determine whether the extant Scots pine stands are descendants of older native populations that survived the pine decline 4000 years ago, or had instead been planted during the introduction of planted conifers from around $\mathrm{AD}$ 1800. Results from the Breidden Hill pond record indicate that the current populations at that site have been strongly influenced by planting activities in the 1800 s. However, the overwhelming signal from the local alder carr in the early part of the record is likely to have dampened the detection of pine pollen, and thus may not reflect the ecological changes during that period accurately. Moreover, there are uncertainties regarding the overlap between the LM18 and BH18 records, leaving the question regarding the origin of the current Scots pine populations open-ended and in need of further research.

This study contributes to the debate regarding the Scots pine demise in the British Isles and encourages the discussion about the persistence of this species for this particular region. This discussion has important implications for the conservation of woodlands in the area and how Scots pine is considered. This investigation demonstrates the contribution that palaeoecology can make to questions of modern ecology and conservation, and its potential to add new information to long-lasting environmental debates.

\section{Acknowledgements}

This work was undertaken in a collaborative framework between the University of Manchester and the Woodland Trust. Special thanks to Nigel Douglas from the Woodland Trust for assistance and support throughout the project. Particular recognition goes 
to John Moore, Thomas Bishop and Jonathan Yarwood at the University of Manchester Geography Laboratories for assistance during fieldwork and in the laboratory. We would also like to thank Mr. Richard Vickers for allowing us to access the Breidden Hill pond. Finally, many thanks to Natural England and Suckley Farms for permitting access to Lin Can Moss.

\section{Funding}

The author(s) received no financial support for the research, authorship, and/or publication of this article.

\section{ORCID iD}

Dael Sassoon (iD https://orcid.org/0000-0003-3992-2320

\section{References}

Anderson DE, Binney HA and Smith MA (1998) Evidence for abrupt climatic change in northern Scotland between 3900 and 3500 calendar years BP. The Holocene 8(1): 97-103.

Ball MJ, Fife J, Poppe E et al. (1990) Celtic Linguistics/Ieithyddiaeth Geltaidd: Readings in the Brythonic Languages. Festschrift for T. Arwyn Watkins, vol. 68. Amsterdam, The Netherlands: John Benjamins Publishing Company.

Batchelor CR (2009) Middle Holocene Environmental Changes and the History of Yew (Taxus baccata L.) Woodland in the Lower Thames Valley. PhD Thesis, Royal Holloway, University of London, London.

Beales PW (1980) The late Devensian and Flandrian vegetational history of Crose Mere, Shropshire. New Phytologist 85(1): $133-161$.

Belyea LR and Warner BG (1996) Temporal scale and the accumulation of peat in a Sphagnum bog. Canadian Journal of Botany 74(3): 366-377.

Bennett KD and Willis KJ (2001) Pollen. In: Smol P, Birks HJB and Last WM (eds.) Tracking Environmental Change Using Lake Sediments. Volume 3: Terrestrial, Algal, and Siliceous Indicators. Dordrecht, The Netherlands: Kluwer Academic Publishers, pp.5-32.

Bennett KD (1984) The post-glacial history of Pinus sylvestris in the British Isles. Quaternary Science Reviews 3(2-3): 133-155.

Bennett KD (1995) Post-glacial dynamics of pine (Pinus sylvestris) and pinewoods in Scotland. In: Our Pinewood Heritage (ed JR Aldhous), Inverness, 20-22 October 1994, pp.23-39. Sandy: Forestry Commission, The Royal Society for the Protection of Birds, Scottish Natural Heritage.

Bennett KD (1996) Determination of the number of zones in a biostratigraphical sequence. New Phytologist 132(1): 155-170.

Bick D (1996) British Mining No. 30 - Frongoch Lead \& Zinc Mine. Banbury: northern Mine Research Society.

Birks HJB, Deacon J and Peglar S (1975) Pollen maps for the British Isles 5000 years ago. Proceedings of the Royal Society of London, Series B, Biological Sciences 189(1094): 87-105.

Birks HJB and Williams W (1983) Late-quaternary vegetational history of the inner Hebrides. Proceedings of the Royal society of Edinburgh, Section B, Biological Sciences 83: 269-292.

Birks HJB (1989) Holocene isochrone maps and patterns of treespreading in the British Isles. Journal of Biogeography 16(6): 503-540.

Blaauw M (2010) Methods and code for 'classical' age-modelling of radiocarbon sequences. Quaternary Geochronology 5(5): $512-518$.

Blackford JJ, Edwards KJ, Dugmore AJ et al. (1992) Icelandic volcanic ash and the mid-Holocene Scots pine (Pinus sylvestris) pollen decline in northern Scotland. The Holocene 2(3): 260-265.

Blackford JJ (2000) Charcoal fragments in surface samples following a fire and the implications for interpretation of sub- fossil charcoal data. Palaeogeography, Palaeoclimatology, Palaeoecology 164(1): 33-42.

Blundell A and Barber K (2005) A 2800-year palaeoclimatic record from Tore Hill Moss, Strathspey, Scotland: The need for a multi-proxy approach to peat-based climate reconstructions. Quaternary Science Reviews 24(10-11): 1261-1277.

Botanica Society of Britain and Ireland (BSBI) (2018) Pinus sylvestris distribution map. Available at: www.bsbi.org/ maps?taxonid=2cd4p9h.1xe (accessed 19 June 2018).

Bradshaw RH and Browne P (1987) Changing patterns in the post-glacial distribution of Pinus sylvestris in Ireland. Journal of Biogeography 14(3): 237-248.

Brown AD (2010) Pollen analysis and planted ancient woodland restoration strategies: A case study from the Wentwood, southeast Wales, UK. Vegetation History and Archaeobotany 19(2): 79-90.

Buckland PC, Pearson MP, Wigley A et al. (2001) Is there anybody out there? A reconsideration of the environmental evidence from the Breiddin Hillfort, Powys, Wales. The Antiquaries Journal 81: 51-76.

Carlisle A and Brown AHF (1968) Pinus sylvestris L. Journal of Ecology 56(1): 269-307.

Chambers FM (1980) Aspects of vegetational history and blanket peat initiation in upland south Wales. PhD Thesis, Cardiff University, Cardiff.

Chambers FM and Price SM (1988) The environmental setting of Erwwen and Moel y Gerddi: prehistoric enclosures in upland Ardudwy, north Wales. Proceedings of the Prehistoric Society, 54: 93-100.

Chambers FM, Beilman DW and Yu Z (2011) Methods for determining peat humification and for quantifying peat bulk density, organic matter and carbon content for palaeostudies of climate and peatland carbon dynamics. International Mire Conservation Group and International Peat Society 7(7): $1-10$.

Chiverrell RC (2001) A proxy record of late-Holocene climate change from May Moss, northeast England. Journal of Quaternary Science 16(1): 9-29.

Chow TJ, Snyder CB and Earal JL (1975) Isotope Ratios of Lead as Pollutant Source Indicators. Vienna, Austria: International Atomic Energy Agency (IAEA).

Clapham AR, Tutin TG and Warburg EF (1962) Flora of the British Isles. Cambridge: Cambridge University Press.

Climate-Data.org (2019) Shrewsbury climate (United Kingdom). Available at: http://www.en.climate-data.org/europe/unitedkingdom/england/shrewsbury-7336/ (accessed 14 September 2020).

Cooney T (1996) Vegetation changes associated with late-Neolithic copper mining in Killarney. In: Delaney $\mathrm{C}$ and Coxon P (eds.) Central Kerry. Field Guide No. 20. Dublin, Ireland: Irish Association for Quaternary Studies, pp.28-32.

Dodson JHR and Bradshaw RHW (1987) A history of vegetation and fire, 6600-present, County Sligo, western Ireland. Boreas 16(2): 113-123.

Edvardsson J, Stoffel M, Corona C et al. (2016) Subfossil peatland trees as proxies for Holocene palaeohydrology and palaeoclimate. Earth-Science Reviews 163: 118-140.

Edwards KJ, Dugmore AJ, Buckland PC et al. (1996) Holocene comment and reply: Hekla-4 ash, the pine decline in northern Ireland and the effective use of tephra isochrones: A comment on Hall, Pilcher and McCormac. The Holocene 6(4): 495-496.

Edwards P, Williams T and Stanley P (2016) Surface water management and encapsulation of mine waste to reduce water pollution from Frongoch Mine, Mid Wales. In: Proceedings IMWA (eds C Drebenstedt and M Paul), Leipzig, Germany, 
July 11-15, 2016. Freiberg: Technische Universität Bergakademie.

Faegri F and Iversen J (1989) Textbook of Pollen Analysis, 4th edn. Chichester: John Wiley and Sons.

Farmer JG, Eades LJ and Graham MC (1999) The lead content and isotopic composition of British coals and their implications for past and present releases of lead to the UK environment. Environmental Geochemistry and Health 21(3): 257-272.

Farmer JG, Eades LJ, MacKenzie AB et al. (1996) Stable lead isotope record of lead pollution in Loch Lomond sediments since 1630 A.D. Environmental Science and Technology 30(10): 3080-3083.

Fletcher W and Ryan P (2018) Radiocarbon constraints on historical peat accumulation rates and atmospheric deposition of heavy metals at Holcroft Moss, Warrington. North West Geography 18(2): 18-28.

Fossitt JA (1994) Late-glacial and Holocene vegetation history of western Donegal, Ireland. Biology and Environment: Proceedings of the Royal Irish Academy 94B(1): 1-31.

Froyd CA (2005) Fossil stomata reveal early pine presence in Scotland: Implications for postglacial colonization analyses. Ecology 86(3): 579-586.

Gavin DG, Fitzpatrick MC, Gugger PF et al. (2014) Climate refugia: Joint inference from fossil records, species distribution models and phylogeography. New Phytologist 204(1): 37-54.

Gear AJ and Huntley B (1991) Rapid changes in the range limits of Scots pine 4000 years ago. Science 251(4993): 544-547.

Glassman SI, Peay KG, Talbot JM et al. (2015) A continental view of pine-associated ectomycorrhizal fungal spore banks: A quiescent functional guild with a strong biogeographic pattern. New phytologist 205(4): 1619-1631.

Godwin H (1940) Pollen analysis and forest history of England and Wales. New Phytologist 39(4): 370-400.

Guest C (1877) The Mabinogion from the Welsh of the Llyfr Coch of Hergest (The Red Book of Hergest) in the Library of Jesus College, Oxford. London: Bernard Quaritch.

Hall VA, Pilcher JR and McCormac FG (1994) Icelandic volcanic ash and the mid-Holocene Scots pine (Pinus sylvestris) decline in the north of Ireland: No correlation. The Holocene 4(1): 79-83.

Hall VA, Pilcher JR and McCormac FG (1996) Hekla-4 ash, the pine decline in northern Ireland and the effective use of tephra isochrones: A reply to Edwards, Dugmore, Buckland, Blackford and Cook. The Holocene 6(4): 496-497.

Hanson Heidelberg Group (2013) Criggion quarry community page. Available at: www.hanson-communities.co.uk/en/site/ criggion-quarry-community-page (accessed 07 August 2020)

Heiri O, Lotter AF, Hausmann S et al. (2003) A chironomidbased. Holocene summer air temperature reconstruction from the Swiss Alps. The Holocene 13(4): 477-484.

Herbert S and Roberts MB (2002) Charles Darwin's notes on his 1831 geological map of Shrewsbury. Archives of Natural History 29(1): 27-29.

Hibbert FA and Switsur VR (1976) Radiocarbon dating of Flandrian pollen zones in Wales and northern England. New Phytologist 77(3): 793-807.

Home C and Jones G (1959) Excavations of Nesscliffe Hill. Transactions of the Shropshire Archaeological Society 56(ii): 129-132.

Horrocks M and D'Costa DM (2003) Stratigraphic palynology in porous soils in humid climates: An example from Pouerua, northern New Zealand. Palynology 27(1): 27-37.

Ingrouille M (1995) Historical Ecology of the British Flora. Berlin, Germany: Springer Science \& Business Media.

Innes J, Blackford J and Chambers F (2006) Kretzschmaria deusta and the Northwest European mid-Holocene Ulmus decline at
Moel y Gerddi, north Wales, United Kingdom. Palynology 30(1): 121-132.

Jones BL (2008) Profile of a Welsh county coalfield-The Denbighshire Coalfield, 1850-1914. PhD Thesis, Cardiff University, Cardiff.

Jones N (2011) An astonishing hoverfly find in Shropshire. Shropshire Entomology 4: 15-16.

Kemp AC, Sommerfield CK, Vane CH et al. (2012) Use of lead isotopes for developing chronologies in recent salt-marsh sediments. Quaternary Geochronology 12: 40-49.

Kinloch BB, Westfall RD and Forrest GI (1986) Caledonian Scots pine: Origins and genetic structure. New Phytologist 104(4): 703-729.

Kneen S and Lageard JGA (2015) COMM2: Vegetation history from Colemere and Clarepool Moss, Shropshire. Report prepared for The Meres and Mosses Landscape Partnership Scheme/Shropshire Wildlife Trust, March 2015.

Lageard JGA, Chambers FM and Thomas PA (1999) Climatic significance of the marginalization of Scots pine (Pinus sylvestris L.) c. $2500 \mathrm{BC}$ at White Moss, south Cheshire, UK. The Holocene 9(3): 321-331.

Lamb HH (1977) Climate: Present, Past and Future, vol. 2. London: Methuen.

Le Roux G, Weiss D, Grattan J et al. (2004) Identifying the sources and timing of ancient and medieval atmospheric lead pollution in England using a peat profile from Lindow bog, Manchester. Journal of Environmental Monitoring 6(5): 502-510.

Linnard W (1982) Welsh Woods and Forests: History and Utilization. Cardiff: National Museum of Wales.

Linnard W (2000) Welsh Woods and Forests: A History. Llandysul: Gomer Press.

McGeever AH and Mitchell FJ (2016) Redefining the natural range of Scots Pine (Pinus sylvestris L.): a newly discovered microrefugium in western Ireland. Journal of Biogeography 43(11): 2199-2208.

McNally A and Doyle G (1984) A study of subfossil pine layers in a raised bog complex in the Irish Midlands: I. Palaeowoodland extent and dynamics. Proceedings of the Royal Irish Academy. Section B: Biological, Geological, and Chemical Science 84B: 57-70.

McVean DN (1956) Ecology of Alnus glutinosa (L.) Gaertn: V. Notes on some British alder populations. Journal of Ecology 44(2): 321-330.

Manning AD, Kesteven J, Stein J et al. (2010) Could native Scots pines (Pinus sylvestris) still persist in northern England and southern Scotland? Plant Ecology and Diversity 3(2): 187201.

Marren P (1990) Woodland Heritage. Newton Abbot: David and Charles.

Mighall TM and Chambers FM (1995) Holocene vegetation history and human impact at Bryn y Castell, Snowdonia, north Wales. New Phytologist 130(2): 299-321.

Mighall TM, Abrahams PW, Grattan JP et al. (2002a) Geochemical evidence for atmospheric pollution derived from prehistoric copper mining at Copa Hill, Cwmystwyth, mid-Wales, UK. Science of the Total Environment 292(1-2): 69-80.

Mighall TM, Grattan JP, Timberlake S et al. (2002b) An atmospheric pollution history for lead-zinc mining from the Ystwyth Valley, Dyfed, mid-Wales, UK as recorded by an upland blanket peat. Geochemistry: Exploration, Environment, Analysis 2(2): 175-184.

Mighall TM, Timberlake S, Martínez-Cortizas A et al. (2017) Did prehistoric and Roman mining and metallurgy have a significant impact on vegetation? Journal of Archaeological Science: Reports 11: 613-625.

Moore PD, Webb JA and Collinson ME (1991) Pollen Analysis. Oxford: Blackwell. 
Mortimer SR, Turner AJ, Brown VK et al. (2000) The nature conservation value of scrub in Britain. JNCC Report No. 308. Peterborough: JNCC.

Mukassabi TA, Polwart A, Coleshaw T et al. (2012) Scots pine seed dynamics on a waterlogged site. Trees 26(4): 1305-1315.

Murdie RE, White RH, Barratt G et al. (2003) Geophysical surveys of Bury Walls hill fort, Shropshire. Archaeological Prospection 10(4): 249-263.

Musson C, Britnell WJ, Smith AG et al. (1991) The Breiddin Hillfort: A Later Prehistoric Settlement in the Welsh Marches, vol. 76. London: Council for British Archaeology.

Natural England (2007) Lowland Grassland Management Handbook. York: Natural England.

Natural England (2018) Lin Can Moss NE. Natural England. Available at: https://designatedsites.naturalengland.org.uk/ PDFsForWeb/Citation/1000221.pdf (accessed 16 July 2018).

Parducci L, Suyama Y, Lascoux M et al. (2005) Ancient DNA from pollen: A genetic record of population history in Scots pine. Molecular Ecology 14(9): 2873-2882.

Parker AG, Goudie AS, Anderson DE et al. (2002) A review of the mid-Holocene elm decline in the British Isles. Progress in Physical Geography 26(1): 1-45.

Payne RJ, Edwards KJ and Blackford JJ (2013) Volcanic impacts on the Holocene vegetation history of Britain and Ireland? A review and meta-analysis of the pollen evidence. Vegetation History and Archaeobotany 22(2): 153-164.

Pearce A (2010) Field Guide to Stiperstones Mines. Shropshire Mines Trust. Newport: Moorebooks.

Pessi AM and Pulkkinen P (1994) Temporal and spatial variation of airborne Scots pine (Pinus sylvestris) pollen. Grana 33(3): 151-157.

Rackham O (1986) The History of the Countryside: The Classic History of Britain's Landscape, Flora and Fauna. London: JM Dent.

Rackham O (1990) Trees and Woodland in the British Landscape, 2nd edn. London: JM Dent \& Sons Ltd.

Rackham O (2003) Ancient Woodland, Its History, Vegetation and Uses in England, 2nd edn. Dalbeattie: Castlepoint Press.

Rackham O (2008) Ancient woodlands: Modern threats. New Phytologist 180(3): 571-586.

Raye L (2014) Broom (Cytisus scoparius) and "pine" (Taxus baccata? Pinus sylvestris?) in 'Breuddwyd Rhonabwy' ('The Dream of Rhonabwy'). Available at: https://historyandnature. wordpress.com/2014/06/08/broom-and-pine-in-rhonabwy/ (accessed 14 September 2020).

Renberg I, Persson MW and Emteryd O (1994) Pre-industrial atmospheric lead contamination detected in Swedish lake sediments. Nature 368(6469): 323-326.

Renberg I, Bindler R and Brännvall ML (2001) Using the historical atmospheric lead- deposition record as a chronological marker in sediment deposits in Europe. The Holocene 11(5): 511-516.

Reimer PJ, Austin WEN, Bard E et al. (2020) The IntCal20 northern hemisphere radiocarbon age calibration curve $(0-55 \mathrm{cal}$ kBP). Radiocarbon 62(4): 725-757.

Ribeiro D, Martins G, Nogueira R et al. (2008) Phosphorus fractionation in volcanic lake sediments (Azores - Portugal). Chemosphere 70(7): 1256-1263.

Rodríguez-González PM, Campelo F, Albuquerque A et al. (2014) Sensitivity of black alder (Alnus glutinosa [L.] Gaertn.) growth to hydrological changes in wetland forests at the rear edge of the species distribution. Plant Ecology 215(2): 233-245.
Rotheray EL (2013) Differences in ecomorphology and microhabitat use of four saproxylic larvae (Diptera, Syrphidae) in Scots pine stump rot holes. Ecological Entomology 38(3): 219-229.

Rothwell JJ, Taylor KG, Chenery SR et al. (2010) Storage and behavior of $\mathrm{As}, \mathrm{Sb}, \mathrm{Pb}$, and $\mathrm{Cu}$ in ombrotrophic peat bogs under contrasting water table conditions. Environmental Science \& Technology 44(22): 8497-8502.

Shackelford N, Hobbs R, Heller N et al. (2013) Finding a middleground: The native/non-native debate. Biological Conservation 158: 55-62.

Shennan I, Long AJ and Horton BP (2015) Handbook of SeaLevel Research. Chichester: John Wiley \& Sons.

Smith AG and Cloutman EW (1988) Reconstruction of Holocene vegetation history in three dimensions at Waun-Fignen-Felen, an upland site in South Wales. Philosophical Transactions of the Royal Society of London B, Biological Sciences 322(1209): 159-219.

Smith AG and Morgan LA (1989) A succession to ombrotrophic bog in the Gwent Levels, and its demise: A Welsh parallel to the peats of the Somerset Levels. New Phytologist 112(1): $145-167$.

Spencer JW and Kirby KJ (1992) An inventory of ancient woodland for England and Wales. Biological conservation 62(2): $77-93$.

Sugita S (2007) Theory of quantitative reconstruction of vegetation II: All you need is LOVE. The Holocene 17(2): 243-257.

Taylor JA (1973) Chronometers and chronicles: A study of palaeo-environments in west central Wales. Progress in Geography 5: 247-334.

Tipping R, Ashmore P, Davies AL et al. (2008) Prehistoric Pinus woodland dynamics in an upland landscape in northern Scotland: The roles of climate change and human impact. Vegetation History and Archaeobotany 17(3): 251-267.

Troels-Smith J (1955) Karakterisering af lose jordater (Characterisation of unconsolidated sediments). Danmarks Geologiske Undersogelse 3(10): 39-73.

Turner TE, Swindles GT and Roucoux KH (2014) Late-Holocene ecohydrological and carbon dynamics of a UK raised bog: Impact of human activity and climate change. Quaternary Science Reviews 84: 65-85.

Twigger SN and Haslam CJ (1991) Environmental change in Shropshire during the last 13,000 years. Field Studies 7: 743-758.

Twigger SN (1988) Late-Holocene palaeoecology and environmental archaeology of six lowland lakes and bogs in North Shropshire. PhD Thesis, University of Southampton, Southampton.

Van der Valk AG (1981) Succession in wetlands: A Gleasonian approach. Ecology 62(3): 688-696.

Walker R (1978) Diatom and pollen studies of a sediment profile from Melynllyn, a mountain tarn in Snowdonia, North Wales. New Phytologist 81(3): 791-804.

Watkins R, Scourse JD and Allen JR (2007) The Holocene vegetation history of the Arfon Platform, north Wales, UK. Boreas 36(2): 170-181.

Watts WW (1885) On the igneous and associated rocks of the Breidden Hills in East Montgomeryshire and West Shropshire. Quarterly Journal of the Geological Society 41(1-4): 532-546.

Woodland Trust (2009) Ancient woods: A guide for woodland owners and managers. Report, Woodland Trust, Grantham, September. 